Lipford, and Slice

Who Pays for College Athletic Spending?

An Examination of the Evidence

\author{
Jody W. Lipford \\ Presbyterian College
}

Jerry K. Slice

Presbyterian College 
Who Pays for College Athletic Spending

\begin{abstract}
College athletics is a major business in the United States. Collegiate sports teams generate billions of dollars in revenues, but they also incur billions of dollars in costs, and for the vast majority of athletic teams, revenues do not cover costs. When athletic programs do not cover their costs, the institutional budget must fund these expenses. In this paper, we demonstrate that an institution's athletic subsidy per student is dependent on the institution's number of students. Further, we find that institutions where the athletic subsidy per student is high enroll a disproportionate share of students who are economically disadvantaged and less qualified academically.
\end{abstract}




\section{Who Pays for College Athletic Spending? An Examination of the Evidence}

College sports in the United States are a big business. With billions in revenues and millions of ardent fans, collegiate athletics is a major player in the entertainment industry. Nonetheless, like their host educational institutions, college athletic programs are not-for-profit. Although some programs generate revenues in excess of costs, most do not. Using 2014-15 data from the USA Today, Alsher (2016) reports that 219 of 231 public, National Collegiate Athletic Association (NCAA) Division I athletic programs operated at a loss.

When college athletic programs operate at a loss, the institutional budget must fund the deficit (Center for College Affordability and Productivity, 2010). For athletic programs in the USA Today data set, subsidies from the institutional budget vary widely, but can reach into the tens of millions of dollars, with an average of almost 54 percent of athletic revenues and a still higher median of nearly 66 percent of athletic revenues.

Many researchers argue and present evidence that even if a college athletic program operates at an accounting loss, the funds transferred from the institutional budget are an investment with a high rate of return (Fort \& Winfree, 2013). On the other hand, other researchers present evidence that the rate of return on institutional investment in athletics is negligible--perhaps zero or negative--or highly variable, depending on athletic success (Frank, 2004 and Zimbalist, 2010).

Our purpose in this paper is not to engage this debate. Rather, our purpose is first to look closely across the landscape of collegiate athletic programs to uncover the determinants of the institutional subsidy to fund athletics on a perstudent basis. We find that institution size, as measured by the number of undergraduates, is a critical factor. From here, we move to our second purpose, which is to identify how student characteristics vary across institutions that heavily or lightly subsidize their athletic programs. We find that students who face financial and academic challenges are more likely to attend institutions that provide relatively high subsidies to their athletic programs.

Our paper is organized as follows. In the following section, we provide a brief review of the literature on the benefits and costs of college athletics. Next, we present the empirical model we used to estimate per-student subsidies across a sample of institutions. We then turn to the empirical estimates in which we present evidence of three key findings: (1) that athletic subsidies on a per-student basis fall with the number of undergraduates enrolled at an institution, (2) that students with financial and academic difficulties are more likely to attend small institutions where the per-student subsidy is higher, so that (3) students with financial and academic difficulties pay differentially more to fund collegiate athletics than their more affluent and academically-qualified peers, who attend 
larger institutions. We review the key implications of our findings and offer concluding thoughts in a final section.

\section{College Athletic Spending: A Review of the Literature}

The literature on the benefits of athletic expenditures by institutions of higher education is rich and extensive, and the results are diverse. Much of the diversity can be attributed to variations in the institutions examined. For instance, are institutions in the study large, flagship institutions in prestigious conferences with a rich athletic heritage, or are they small schools playing at the mid-major level in second-tier conferences composed of members with limited resources and little potential for athletic success? Methodologies also range widely, from case studies of individual schools to in-depth statistical analyses of large databases.

There is substantial scholarly literature which suggests that athletic expenditures are beneficial to colleges and universities. Fort and Winfree (2013) argue forcefully that expenditures on college athletics are an investment that yields a high return to the institution, and numerous studies support this claim. McCormick and Tinsley (1987), for example, found a positive relationship between athletic expenditures, SAT scores, and academic success, especially for schools that play in major conferences. Similarly, Mixon (1995), Mixon, Trevino, and Minto (2004), and Mixon and Trevino (2005) concluded that athletic success in football results in improved academic success and freshman retention. These results were reinforced by Pope and Pope (2009), who found that athletic success by the top football and basketball teams increases applications and SAT scores. Tucker and Amato (1993) corroborate this result for football though not for basketball, and Toma and Cross (1996) found increases in applications following championship seasons, but few measurable impacts on SAT scores or other measures of student quality. Other researchers conclude that athletics brings higher graduation rates and donations (Stinson, Marquardt, \& Chandly, 2012), a stronger sense of community (Kelly \& Dixon 2011), and the development of leadership and time-management skills, teamwork, and character for participants (Denhart, Villwock, \& Vedder, 2009).

On the other hand, numerous researchers question these benefits or their magnitude. Frank (2004) summarizes the findings of many empirical studies in a paper prepared for the Knight Commission on Intercollegiate Athletics with the statement, "The findings reported in these studies are mixed, but the overall message is easily summarized: It is that if success in athletics does generate the indirect benefits in question, the effects are almost surely small" (p. 1). In a study commissioned by the National Collegiate Athletic Association (NCAA) in 2003, Litan, Orszag, and Orszag found positive effects in SAT scores from athletic success, but the effects were small and statistically insignificant, a finding similar 
to those of Smith (2009) and Zoda (2012). In another NCAA-commissioned study, Orszag and Orszag (2005) found that schools moving from NCAA Division II to Division I increase debt, but do not observe significant increases in enrollment.

Other studies focus on the magnitude of athletic expenditures and students' misperceptions of institutional support for this spending. Zimbalist (2010) considers athletic expenditures excessive, and Denhart, Ridpath, and Vedder (2011) charge that they lack transparency as well. In a case study of Ohio University, these researchers determined that most students are aware of university fees, but underestimate their size and are largely unaware that these revenues subsidize intercollegiate athletics. Further, their surveys indicate that intercollegiate athletics are unimportant to the majority of students. Ridpath, Smith, Garrett, and Robe (2015) expanded the survey beyond Ohio University to students of all schools in the Mid-American Conference. The results are similar: students desire a reduction in fees for intercollegiate athletics and consider athletics unimportant. Ridpath, Fattlar, and Yiamouyiannis (2012) report similar findings in another study of the Mid-American Conference. Denhart and Vedder (2010) and Hartsell (2015) describe athletic fees and subsidies as a "regressive tax" that is higher at mid-major schools competing in less prestigious conferences. Further, they found that fees are disproportionately higher at schools where the percentage of students receiving Pell grants is higher. These findings are consistent with Lipford and Slice's (2017) research that shows athletic expenditures are largely fixed by NCAA division, so that schools with small enrollments playing in the upper divisions face high costs per undergraduate.

Our work builds on this analysis of athletic fees and subsidies in an effort to explain their size and determine which students pay the most to fund their schools' athletic programs.

\section{Method}

The amount of subsidy per student that goes to college athletics varies significantly across institutions of higher education. To analyze and identify key factors that explain this difference, we use regression analysis that, in turn, sheds important light on the question of who pays. Before presenting these results, we describe the data we used to estimate them.

\section{The Data}

In a 2015 article, The Chronicle of Higher Education provides detailed data on the revenues and costs of collegiate athletic programs for a sample of 205 NCAA Division I state schools for the years 2010 to 2014 (Wolverton, Hallman, Shifflett, 
\& Kambhampati, 2015). We use data from this article to obtain values of the institutional subsidy to college athletics. The authors of the report calculate the institutional subsidy to athletics as the sum of four components: (1) student fees for athletics, (2) state, municipal, federal and other government appropriations made in support of the operations of college athletics, (3) institutional resources for the current operations of intercollegiate athletics, as well as all unrestricted funds allocated to the athletics department by the university (e.g., state funds, tuition, tuition waivers and transfers), including federal work study support for student workers employed by athletics, and (4) facilities and services provided by the institution not charged to athletics. All values are adjusted for inflation.

For additional data, we use U.S. Department of Education data collected under the Equity in Athletics Disclosure Act (EADA) of 1994 to obtain values of undergraduate enrollment and total athletes by institution. The National Center for Education Statistics, also under the U.S. Department of Education, provides the Integrated Postsecondary Education Data System (IPEDS) that includes the characteristics that we use to measure the financial capability and academic readiness of college students.

\section{Data Analysis}

The equation we estimated to determine per-student subsidies to athletics is given below:

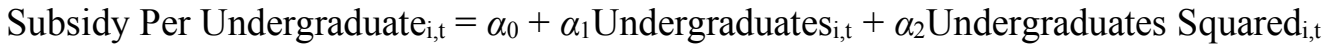
$+\alpha_{3}$ Athletes $_{\mathrm{i}, \mathrm{t}}+\alpha_{4}$ Athletes Squared $_{\mathrm{i}, \mathrm{t}}+\alpha_{5}$ DIAA $_{\mathrm{i}, \mathrm{t}}+\alpha_{6}$ DIAAA $_{\mathrm{i}, \mathrm{t}}+\Sigma_{\mathrm{j}} \alpha_{\mathrm{j}}$ Conference $_{\mathrm{i}, \mathrm{t}}+$ $\Sigma_{\mathrm{k}} \alpha_{\mathrm{k}}$Year $_{\mathrm{i}, \mathrm{t}}+\varepsilon_{\mathrm{i}, \mathrm{t}}$.

We model the subsidy per undergraduate as a function of the number of undergraduates, because large schools often have athletic programs that generate significant revenues, whereas small schools usually do not. Further, athletic costs at large schools are spread over many students, unlike the case for small schools. Both factors lead us to expect that subsidies per undergraduate decrease with the number of students. We include the square of undergraduates to test for the rate of decline, and we expect its value to be positive. We use an institution's total number of athletes as a proxy for the size of its athletic program and hypothesize that per-student subsidies increase with larger athletic programs. Again, we include a squared term to measure the rate of change.

Each NCAA division represents a different level of financial commitment to college athletics, including obligations to comply with different NCAA mandates on the number of sports, scholarships, and coaches, among other variables. To account for these differences, we include dummy variables for 
divisions DIAA and DIAAA. DIAA mandates are less costly than DIA mandates, and DIAAA mandates are less costly still because schools in this division do not field football teams. Based upon costs alone, we hypothesize that subsidies per student will be lower for DIAA and DIAAA schools. On the other hand, these schools typically generate less revenue from athletics, so the effect of NCAA division is ambiguous.

Within NCAA divisions, athletic conferences vary dramatically in their financial commitment to athletics and their ability to generate revenues. The Power Five conferences (the Atlantic Coast Conference, the Big Ten, the Big Twelve, the Pacific Twelve, and the Southeastern Conference) generate enormous revenues through post-season football bowl appearances, the NCAA basketball tournament, gate receipts, and lucrative television contracts. Teams in these conferences also split revenues through conference revenue-sharing agreements. On the other hand, teams in other conferences generate significantly less revenue to offset athletic costs. To account for conference differences, we include dummy variables for all Division I conferences represented by the teams included in the sample, except for the Big Ten conference, which has its subsidy valued imbedded in the intercept.

To account for secular trends across time, we also include dummy variables for the years 2011 to 2014 . The value for 2010 is also imbedded in the intercept.

Because the time invariant effects of NCAA division and conference are central to our analysis, we employ a random effects regression model. A Breusch and Pagan Lagrangian multiplier test reveals the random effects model is superior to $\operatorname{OLS}\left(\chi^{2}=1381.89\right)$. The sample contains data on 203 institutions and a total of 1002 observations. (We omitted observations from schools without at least three consecutive years of data at the same NCAA classification.)

\section{Results}

\section{The Estimates of Subsidy per Student}

The results of our estimate of the above equation are reported in Table. 1. The estimated equation is highly statistically significant, and the overall fit is high.

Turning to the variables of key interest, the number of undergraduates and the square of this value, we found that in accordance with our expectations, the per-student subsidy falls as the number of students rises with a rate of decline that decreases. This result is a highlight of our findings: the amount of subsidy per student depends critically upon the size of the school a student attends, with small schools allocating significantly more resources to athletics on a per-student basis than medium and large schools. 
Other findings are also consistent with our expectations. Large athletic programs, as measured by total athletes and the square of this value, require greater subsidies. The coefficients on NCAA division indicate that in spite of significant revenues, Division IA schools require the heaviest per-student subsidies. DIAA schools subsidize athletics almost $\$ 82$ less per student, and DIAAA schools subsidize athletics almost $\$ 300$ less per student.

The conference dummy variables show significant variance. Of interest, there is no statistically significant difference in the subsidy per student among the Power Five conferences. Of the remaining conferences, the coefficients are positive, indicating subsidies per student at least equal to those of the Power Five conferences. Twenty conferences - those with statistically significant coefficients -- provide subsidies hundreds of dollars more per student.

Last, the year dummy variables indicate a trend in favor of greater subsidies, with the 2014 subsidy almost $\$ 120$ more per student than in 2010 .

Figure 1 provides a graph of the relation between per-student subsidies and the number of undergraduates for three conferences. The top curve represents the Mid-American Conference, where per-student athletic subsidies are highest. (The Big South Conference subsidy is higher, but when this value is adjusted for NCAA division and number of athletes, the per-student subsidy is higher for the MidAmerican Conference.) The bottom curve is for the low-subsidy Southeastern Conference. As shown in the figure, the SEC subsidy is negative - revenues exceed costs - at around 30,000 students. The Southwestern Athletic Conference represents a medium-subsidy conference, as measured by the conference coefficients. However, this conference illustrates the importance of NCAA division. It lowers per-student subsidies by playing at the DIAA division instead of the DIA division, so that its curve lies less than half-way between the MidAmerican and Southeastern Conferences. 
Lipford, and Slice

Table 1.

Estimates of subsidy per student: random effects model

Variable

Undergraduates

Undergraduates Squared

Athletes

Athletes Squared

D1AA

D1AAA

American Athletic Conference

American East Conference

Atlantic 10 Conference

Atlantic Coast Conference

Atlantic Sun Conference

Big 12 Conference

Big East Conference

Big Sky Conference

Big South Conference

Big West Conference

Colonial Athletic Association

Conference USA

Horizon League

Great West Conference

Independent

Mid-American Conference

Mid-Eastern Athletic Conference

Missouri Valley Conference

Mountain West Conference

Northeast Conference

Ohio Valley Conference

Pacific 12 Conference

Southeastern Conference

Southern Conference

Southland Conference

Southwestern Athletic Conference

Sun Belt Conference

The Summit League

Western Athletic Association

Year 2011

Year 2012

Year 2013

Year 2014

Constant

\begin{tabular}{|c|}
\hline Coefficient \\
\hline-0.095 \\
\hline $1.25 \mathrm{e}^{-06}$ \\
\hline 1.181 \\
\hline-0.001 \\
\hline-81.77 \\
\hline-298.72 \\
\hline 512.72 \\
\hline 566.86 \\
\hline 570.76 \\
\hline-28.76 \\
\hline 223.64 \\
\hline-48.96 \\
\hline 187.52 \\
\hline 232.10 \\
\hline 661.08 \\
\hline 561.72 \\
\hline 527.09 \\
\hline 454.97 \\
\hline 256.17 \\
\hline 159.70 \\
\hline 500.74 \\
\hline 573.50 \\
\hline 342.31 \\
\hline 109.10 \\
\hline 349.57 \\
\hline 560.81 \\
\hline 172.85 \\
\hline 155.04 \\
\hline-147.15 \\
\hline 449.59 \\
\hline 289.94 \\
\hline 267.59 \\
\hline 367.18 \\
\hline 222.61 \\
\hline 322.75 \\
\hline 34.20 \\
\hline 59.40 \\
\hline 92.18 \\
\hline 119.62 \\
\hline 1370.78 \\
\hline
\end{tabular}

$Z$-score

$-12.03 * * *$

$8.47 * * *$

$3.74 * * *$

$-3.25 * * *$

$-1.66 *$

$-4.24 * * *$

$5.60 * * *$

$3.51 * * *$

$5.16 * * *$

$-0.33$

1.60

$-0.61$

$2.30 * *$

$2.06 * *$

$4.24 * * *$

$4.60 * * *$

$5.06 * * *$

$5.07 * * *$

1.87 *

1.36

$3.56 * * *$

$4.74 * * *$

$2.11 * *$

0.67

$3.55 * * *$

$1.65^{*}$

1.16

1.57

$-1.61$

$3.97 * * *$

2.56 ***

1.63

$3.93 * * *$

1.86*

$3.31 * * *$

$2.84 * * *$

$4.79 * * *$

$7.21 * * *$

$9.16 * * *$

$8.59 * * *$

Note: $* * * p<0.01, * * p<0.05, * p<0.1, R^{2}$ within $=0.25, R^{2}$ between $=0.70, R^{2}$ overall $=0.68$, Wald $\chi^{2}=703.09^{* * *}, N=1002$, number of groups $=203$ 


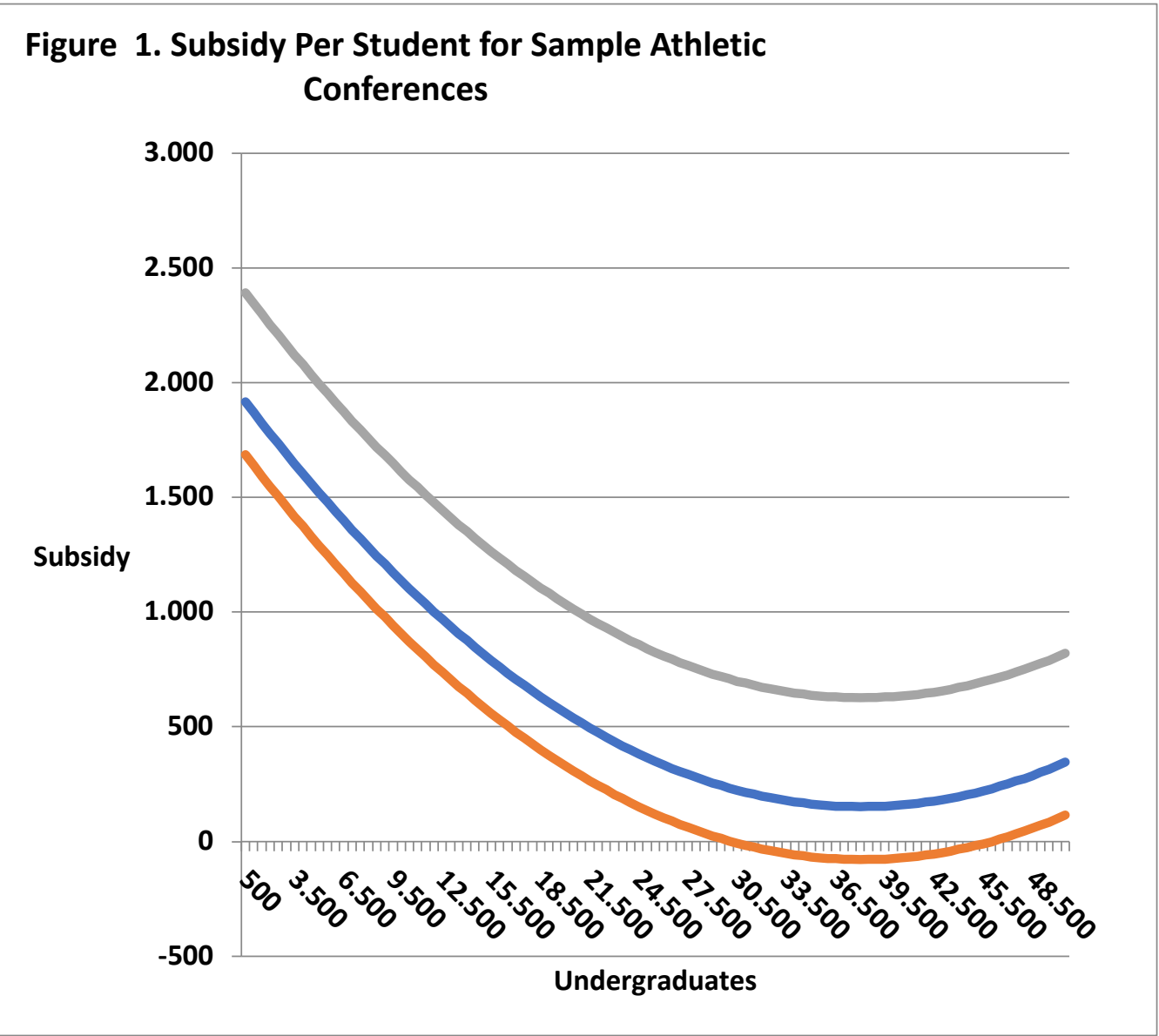

Correlations between Student Characteristics and the Number of Undergraduates

The regression results show clearly the important link between athletic subsidies per student and the number of undergraduates at the institution in which a student is enrolled. We extend this analysis by asking if there are differences in the financial and academic capabilities of students across institution size. Our hypothesis is that students with the most financial and academic capability are more likely to attend large, prestigious, flagship universities and colleges, and that students who face greater financial and academic challenges are more likely to attend small, less prestigious, "second-tier" universities and colleges.

To test this hypothesis, we use IPEDS data on the share of first-time undergraduates receiving Pell grants, the share of first-time undergraduates receiving student loans, the graduation rate, and the composite ACT score, for 
each institution and year in the sample. Our interest in this analysis is in simple correlation and association and not causation. School size does not "cause" student financial or academic capability. As a result, we emphasize simple scatterplots, but then present elementary regression results to further test our findings. Support for our hypothesis is strong.

Figures $2-5$ provide scatterplots of the student characteristics against the number of undergraduates. Looking first at financial capability, Figure 2 shows that as the number of undergraduates increases, the share of first-time undergraduates receiving Pell grants declines.

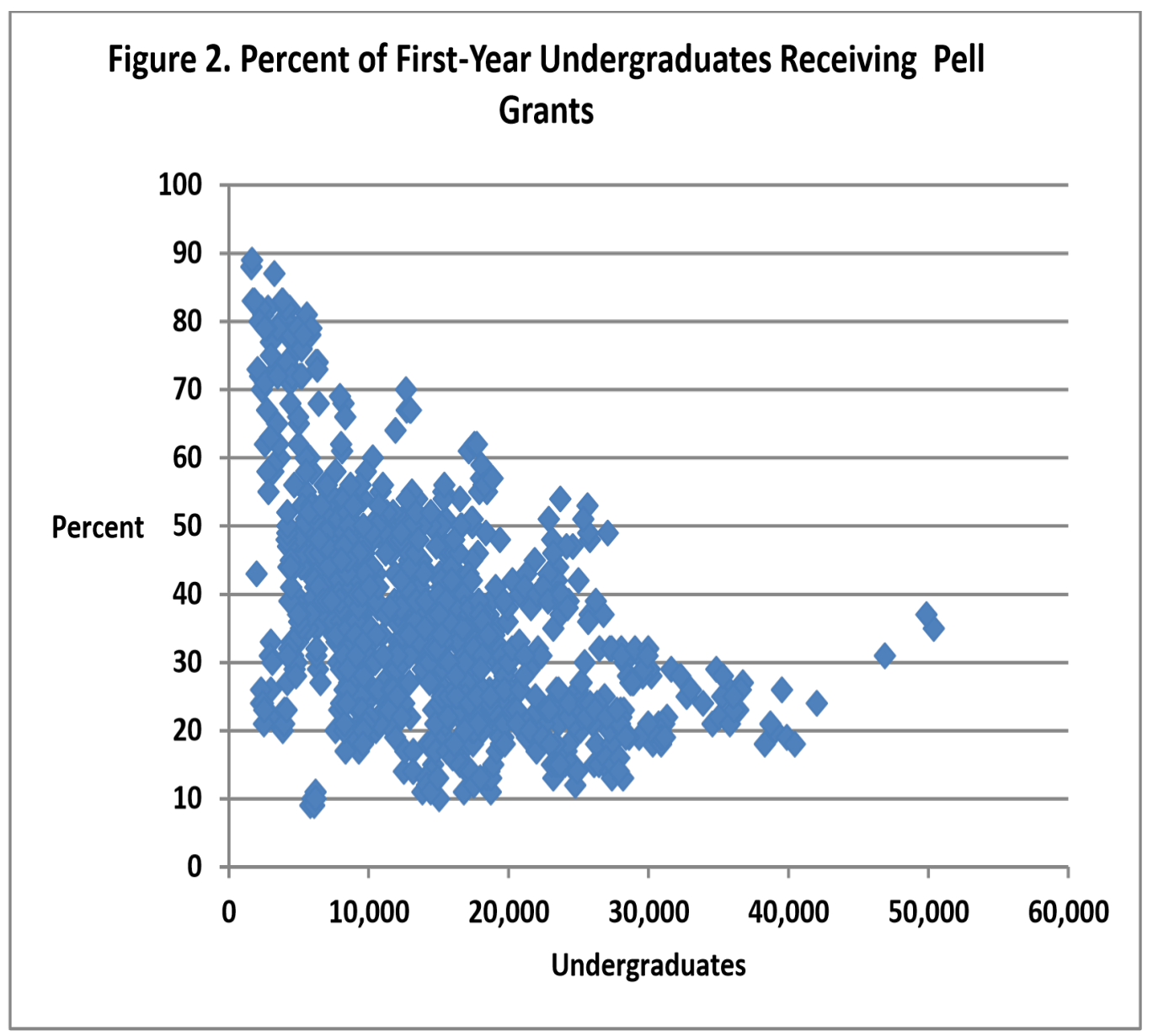

Figure 3 provides a similar scatterplot for the share of first-time undergraduates receiving student loans: the share of students with loans is inversely correlated with the number of undergraduates. These scatterplots indicate that students with the greatest ability to pay are more likely to attend large schools, where athletic subsidies per student are lower. Students with the least 
ability to pay are more likely to attend small schools, where per-student athletic subsidies are higher.

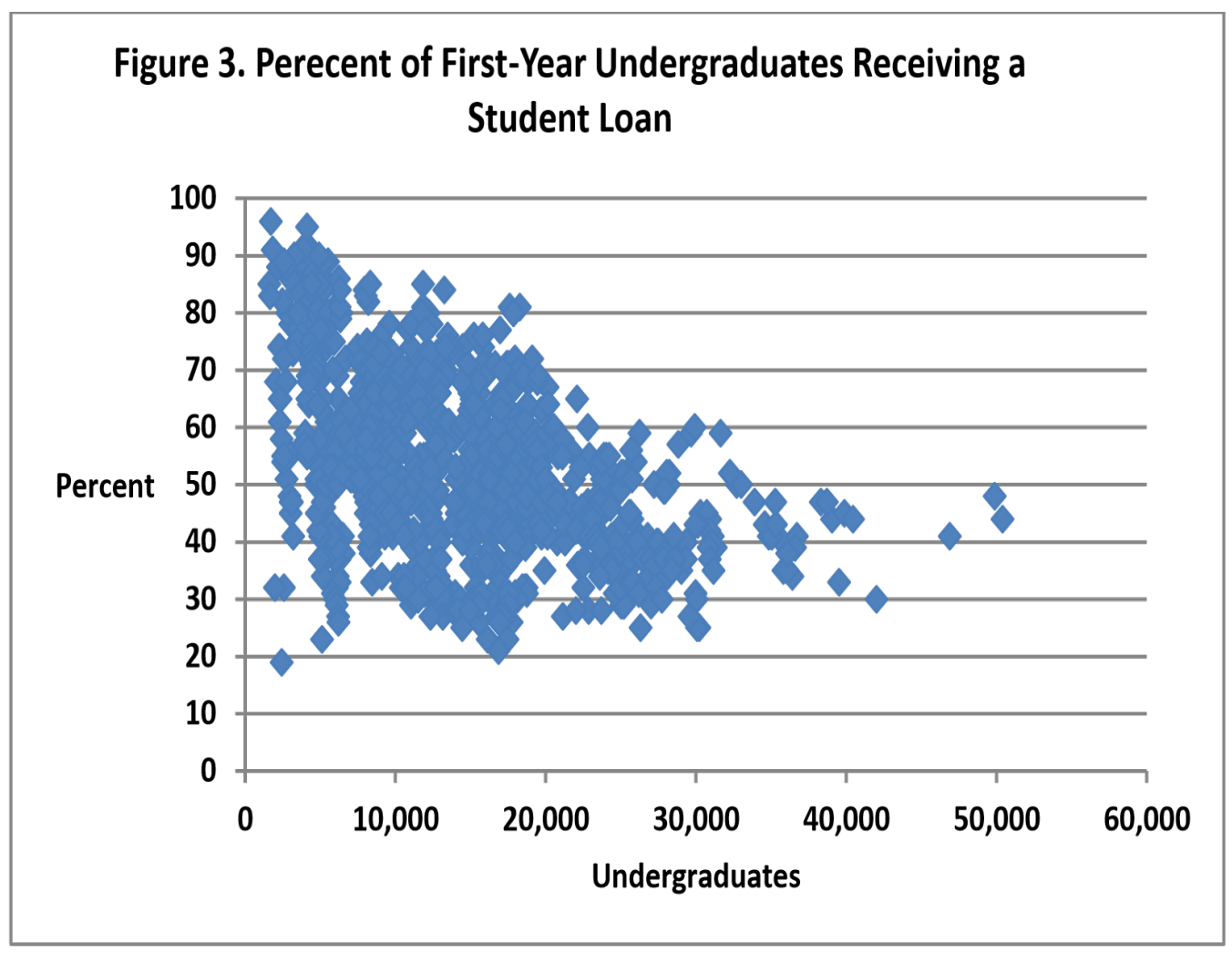

Turning to academic potential, we find that less-gifted students are more likely to attend small schools. The graduation rate is lowest at small schools and rises markedly with the number of undergraduates, as shown in Figure 4. The composite ACT score of the bottom $25^{\text {th }}$ percentile of students is also lowest for small schools, as shown in Figure 5. (Similar unreported results hold for the top $75^{\text {th }}$ percentile of composite ACT scores.)

In Table 2, we present regression results for each student characteristic against the number of undergraduates with year dummy variables to capture any secular trends. We present OLS and GLS/Random Effects estimates in each case. Regardless of specification, the number of undergraduates is correlated with the student characteristic in the expected direction and at a statistically significant level. Students facing financial and academic challenges are differentially more likely to attend small schools, where athletic subsidies are greater on a per-student basis. 
Lipford, and Slice

Figure 4. Graduation Rate

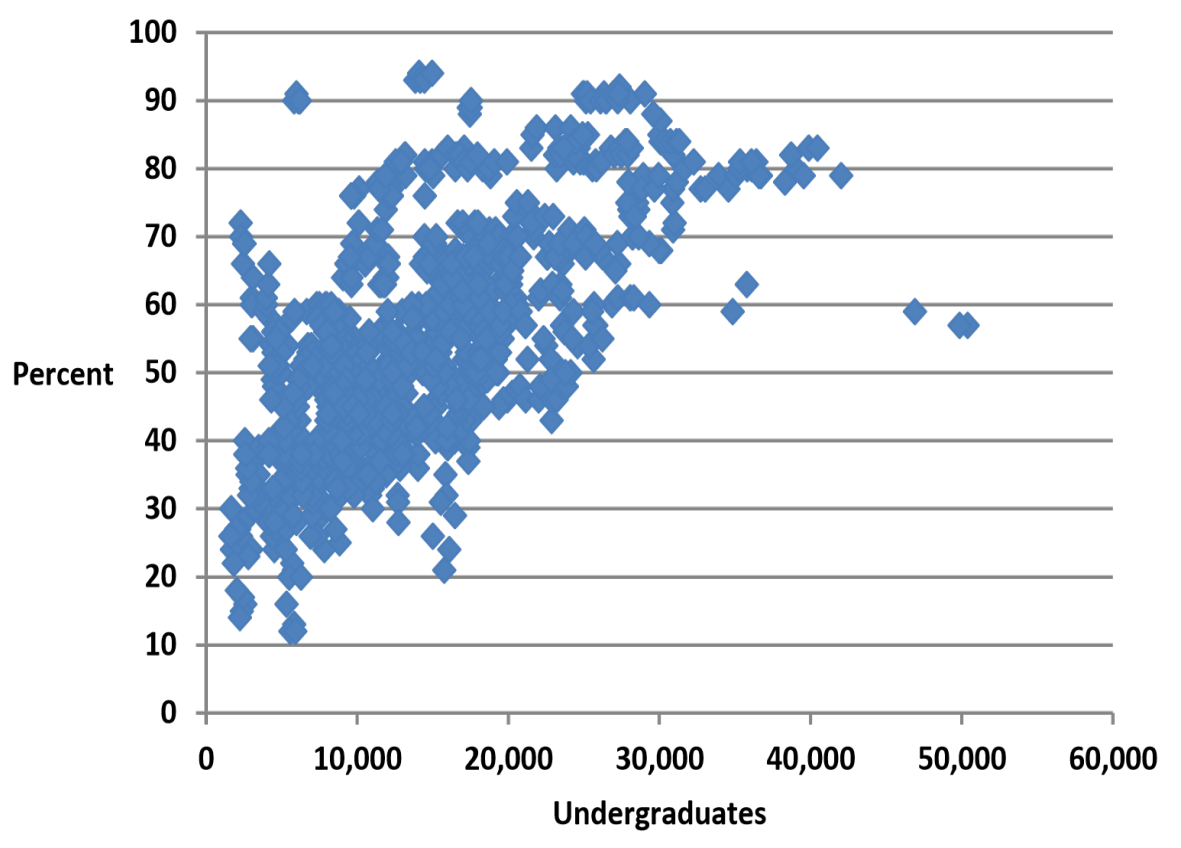

Figure 5. ACT Score of 25th Percentile of Undergraduates

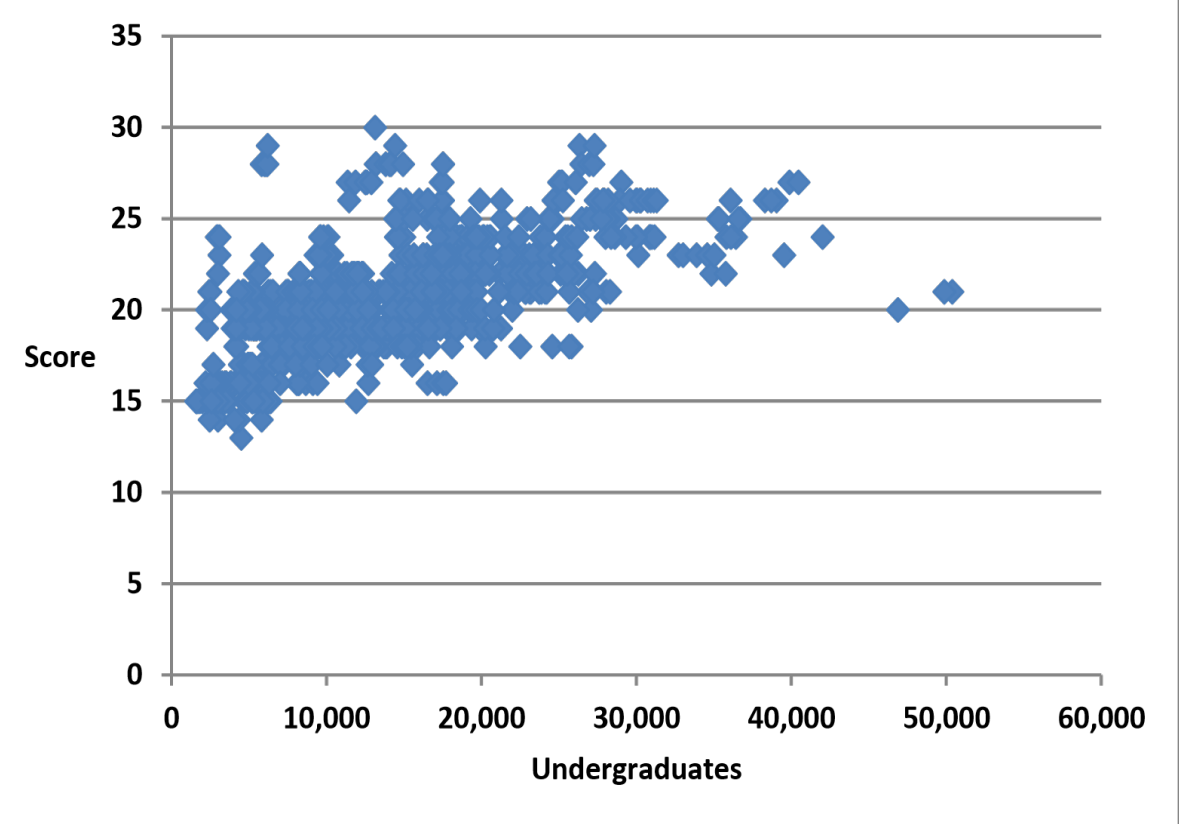




\section{Who Pays for College Athletic Spending}

Table 2.

Estimates of Correlations between Student Characteristics and Number of Undergraduates

Dependent Variable Percent of Students Receiving Pell Grants

OLS OLS GLS/RE

Variable

Under-graduates

Year 2011

Year 2012

Year 2013

Year 2014

Constant

Adj. $R^{2}$

F-stat

$\mathrm{R}^{2}$ overall

Wald $\chi^{2}$

$\mathrm{N}$

Dependent Variable

1002 Coefficient/(t- or $Z$-Score $)$

$$
\begin{gathered}
-0.001 / \\
(-18.71) * * *
\end{gathered}
$$$$
-0.001 /
$$$$
(-18.35)^{* * *}
$$$$
4.81 /
$$$$
(3.58)^{* * *}
$$$$
5.19 /
$$$$
(3.88)^{* * *}
$$$$
4.36 /
$$$$
(3.26)^{* * *}
$$$$
4.24 /
$$$$
\begin{array}{r}
(3.15)^{* * *} \\
46.70 /
\end{array}
$$$$
(38.34)^{* * *}
$$$$
0.26
$$$$
71.03 * * *
$$

$330.13 * * *$

Graduation Rate
OLS

OLS

Variable

Under-graduates

Year 2011

Year 2012

Year 2013

Year 2014

Constant

Adj. $R^{2}$

F-stat

$\mathrm{R}^{2}$ overall

Wald $\chi^{2}$

$\mathrm{N}$

Note: $p^{* * *}<0.01,{ }^{* *} p<0.05, * p<0.1$
Percent of Students Receiving Student Loans

$\begin{array}{ccc}\text { OLS } & \text { OLS } & \text { GLS/R } \\ & \text { Coefficient/(t- or } Z \text {-Score }) & \\ -0.0009 / & -0.0009 /(- & -0.0007 / \\ 16.49)^{* * *}(-16.54)^{* * *} & & (-6.97)^{* * *} \\ & 1.55 / & 1.49 / \\ & (1.18) & (2.83)^{* * *} \\ & 3.62 / & 3.53 / \\ & (2.77)^{* * *} & (6.73)^{* * *} \\ & 2.10 / & 2.06 / \\ & (1.61) & (3.91)^{* * *} \\ 65.50 / & 0.96 / & 0.93 / \\ (76.27)^{* * *} & (0.73) & (1.76)^{*} \\ 0.21 & 63.85 / & 61.44 / \\ 271.96^{* * *} & (53.62)^{* * *} & (36.62)^{* * *} \\ & 0.22 & \\ 1002 & 56.35^{* * *} & \\ & & 0.22 \\ & 1002 & 1002\end{array}$

ACT Composite, 25 $^{\text {th }}$ Percentile

GLS/RE

OLS

OLS

GLS/RE

\begin{tabular}{ccccc}
\multicolumn{2}{c}{ Coefficient/(t- or $\boldsymbol{Z}$-Score $)$} & & \multicolumn{2}{c}{ Coefficient/(t- or $\boldsymbol{Z}$-Score) } \\
$0.0013 /$ & $0.0013 /$ & $0.0004 /$ & $0.0002 /$ & $0.0002 /$ \\
$(26.20)^{* * *}$ & $(26.18)^{* * *}$ & $(6.30)^{* * *}$ & $(21.94)^{* * *}$ & $(21.95)^{* * *}$ \\
& $0.28 /$ & $0.44 /$ & & $0.05 /$ \\
& $(0.22)$ & $(2.05)^{* *}$ & & $(0.22)$ \\
& $0.77 /$ & $1.02 /$ & & $0.12 /$ \\
& $(0.60)$ & $(4.75)^{* * *}$ & & $(0.48)$ \\
& $1.46 /$ & $1.68 /$ & & $0.31 /$ \\
$35.40 /$ & $(1.13)$ & $(7.85)^{* * *}$ & & $(1.28)$ \\
$(41.67)^{* * *}$ & $2.37 /$ & $2.58 /$ & & $0.45 /$ \\
0.41 & $(1.82)^{*}$ & $(11.93)^{* * *}$ & & $(1.83)^{*}$ \\
$686.33^{* * *}$ & $34.43 /$ & $47.11 /$ & $17.77 /$ & $17.58 /$ \\
& $(29.17)^{* * *}$ & $(33.65)^{* * *}$ & $(111.89)^{* * *}$ & $(79.05)^{* * *}$ \\
& 0.41 & & 0.34 & 0.34 \\
1002 & $138.17 * * *$ & & $481.34 * * *$ & $97.30^{* * *}$ \\
& & 0.40 & & \\
& 1002 & $247.83 * * *$ & & 933
\end{tabular}

$0.0001 /$ $(6.35)^{* * *}$

0.08 /

(1.46)

$0.18 /$

$(3.13)^{* * *}$

$0.38 /$

$(6.62)^{* * *}$

$0.49 /$

$(8.57)^{* * *}$

$19.10 /$

$(67.14)^{* * *}$

0.34

$161.31^{* * *}$

933 
Lipford, and Slice

Correlations between Student Characteristics and the Athletic Subsidy per Student

The correlations between student characteristics and the number of undergraduates provide indirect evidence that poorer, less academically-qualified students pay larger subsidies to athletics than their more affluent, academicallygifted counterparts, because they attend smaller schools that generate less athletic revenue and that have fewer students over whom to spread athletic costs.

To examine the relation between student characteristics and athletic subsidies directly, we again present simple scatterplots and regressions, with an emphasis on correlation and association in lieu of causation. In no way do students" financial or academic characteristics "cause" athletic subsidies.

Figures 6 and 7 show that as the shares of first-time undergraduates receiving Pell grants and student loans increase, so do athletic subsidies per student. Students with the greatest financial need attend institutions that spend a larger share of their resources on athletics.

When we consider academic ability, we find that athletic subsidies per student decline with the graduation rate and the composite ACT score of the lowest $25^{\text {th }}$ percentile of students, as shown in Figures 8 and 9. (Similar results hold for the top $75^{\text {th }}$ percentile of composite ACT scores.) Institutions that require few resources to subsidize athletics on a per-student basis attract and enroll students who are more likely to graduate and have higher ACT scores, while students with financial and academic weakness are more likely to attend institutions that allocate more resources to athletics on a per-student basis. 
Figure 6. Subsidy Per Undergraduate Correlated with Percent of First-Year Undergraduates Receiving a Pell Grant

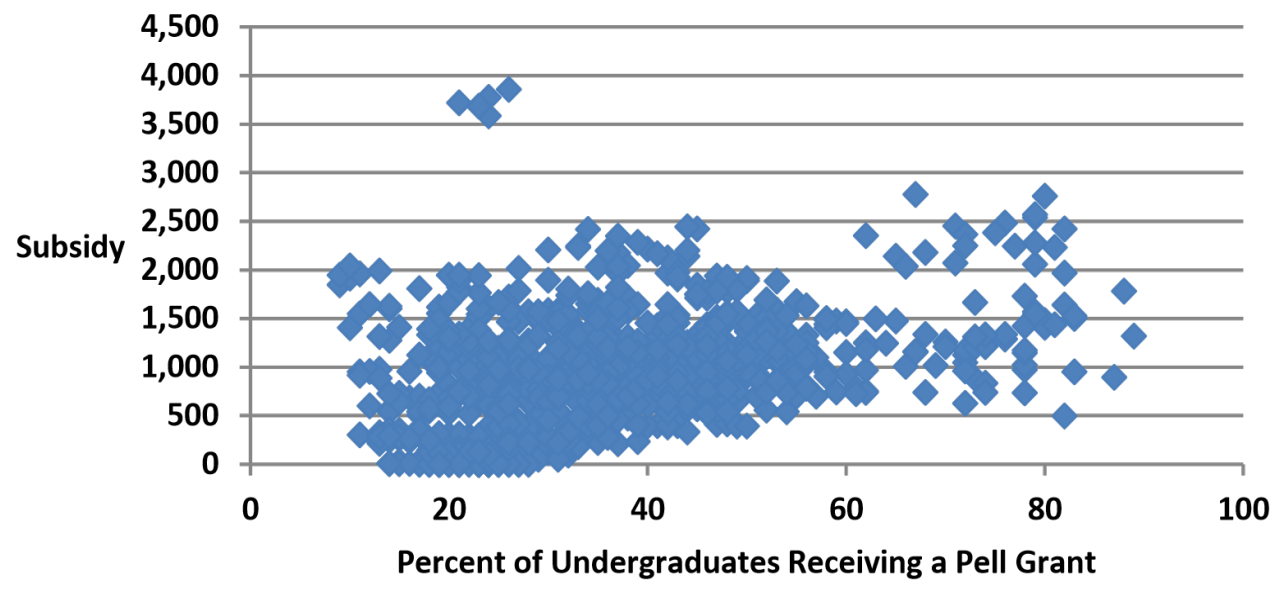

Figure 7. Subsidy Per Undergraduate Correlated with Percent of First-Year Undergraduates Receiving a Student Loan

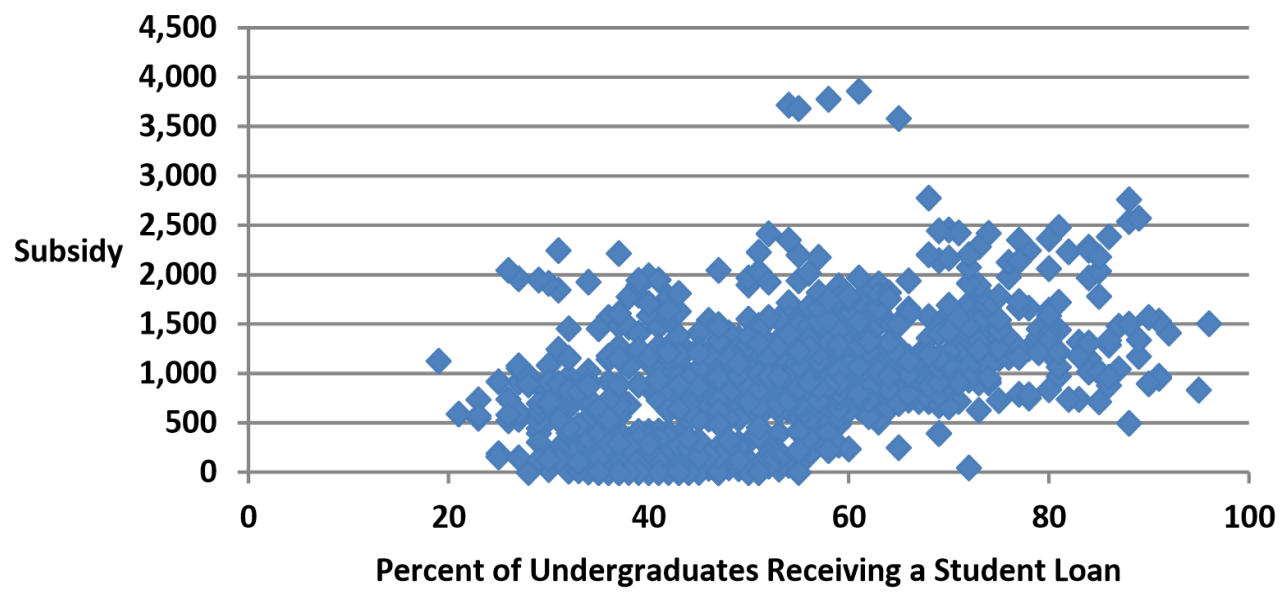


Lipford, and Slice
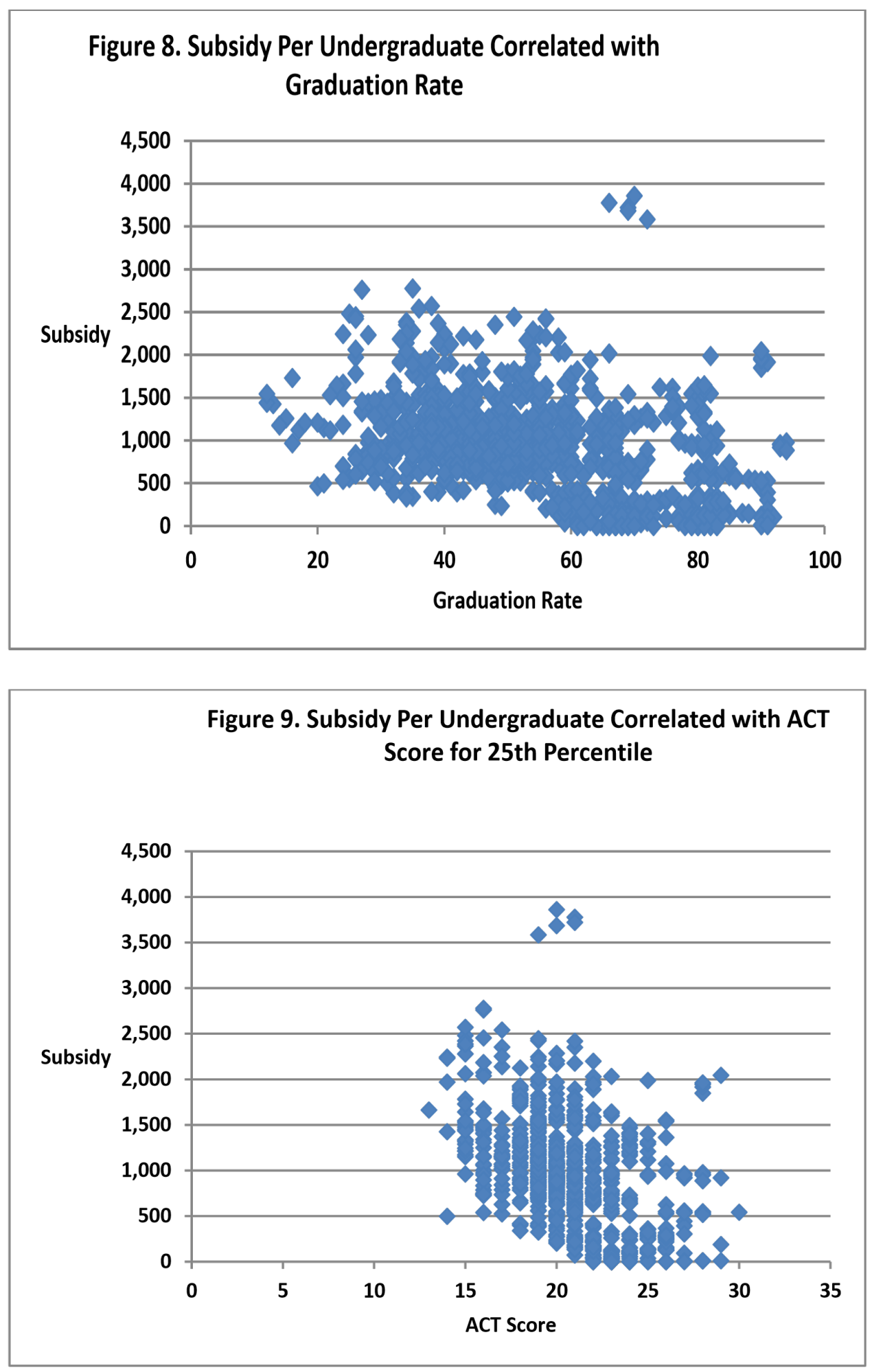
Regression estimates of correlation and association are shown in Table 3. All signs and significance levels accord with our expectations. The percentages of first-time students receiving Pell grants and student loans are positively and significantly correlated with athletic subsidies per undergraduate, and the graduation rate and ACT composite score of the $25^{\text {th }}$ percentile of students are negatively and significantly correlated with athletic subsidies per student.

\section{Discussion}

College athletics is big business in the United States. Revenues exceed costs for some institutions, but the majority of athletic programs require significant funding from the institutional budget. The main purposes of this study are to identify and measure the significant factors that determine institutional transfers to the athletic budget on a per-student basis and to identify the financial and academic characteristics of the students who provide this funding, whether directly or indirectly.

Our analysis yields two main findings.

1. With few exceptions, institutions of higher education subsidize their athletic programs from their wider institutional budgets. This subsidy varies significantly across institutions for numerous reasons, and institution size, as measured by the number of undergraduates, is a critical factor. Large schools are more likely to have athletic programs that generate significant revenues that reduce the subsidy. In addition, on a per-student basis, costs that must be funded from the institutional budget are spread over a large number of students. For small schools, the situation is reversed. Their athletic programs typically generate little revenue, and the costs that the institution must fund are spread over relatively few students, so that the subsidy per student is high.

2. Students who are financially and academically capable are more likely to attend large institutions, typically prestigious, flagship schools that spend relatively few institutional resources on athletics on a per-student basis. On the other hand, students with less financial means and academic potential are more likely to attend small, less prestigious institutions that spend relatively more institutional resources on athletics on a per-student basis. These resources have alternative uses. They could be used to reduce tuition and fees, so that fewer students would require Pell grants or incur debt. Or, these resources could be used to provide additional educational support to help these students succeed. 
Lipford, and Slice

Table 3.

Estimates of Correlations between Subsidy Per Undergraduate and Student Characteristics

\begin{tabular}{|c|c|c|c|c|c|c|c|}
\hline \multirow{2}{*}{$\begin{array}{l}\text { Dependent } \\
\text { Variable }\end{array}$} & \multicolumn{3}{|c|}{ Subsidy Per Undergraduate } & \multirow{2}{*}{$\begin{array}{l}\text { Dependent } \\
\text { Variable }\end{array}$} & \multicolumn{3}{|c|}{ Subsidy Per Undergraduate } \\
\hline & OLS & OLS & GLS/RE & & OLS & OLS & GLS/RE \\
\hline Variable & \multicolumn{3}{|c|}{ Coefficient/(t- or $Z$-Score $)$} & Variable & \multicolumn{3}{|c|}{ Coefficient/(t- or $Z$-Score) } \\
\hline $\begin{array}{l}\text { Percent of } \\
\text { Students } \\
\text { Receiving Pell } \\
\text { Grants }\end{array}$ & $\begin{array}{l}15.02 / \\
(13.74)^{* * *}\end{array}$ & $\begin{array}{l}15.02 / \\
(13.66)^{* * *}\end{array}$ & $\begin{array}{l}3.91 / \\
(2.85)^{* * *}\end{array}$ & $\begin{array}{l}\text { Percent of } \\
\text { Students } \\
\text { Receiving } \\
\text { Student Loans }\end{array}$ & $\begin{array}{l}17.79 / \\
(15.87)^{* * *}\end{array}$ & $\begin{array}{l}17.84 / \\
(15.91)^{* * *}\end{array}$ & $\begin{array}{l}3.49 / \\
(4.26)^{* * *}\end{array}$ \\
\hline Year 2011 & & $\begin{array}{l}-35.66 / \\
(-0.66)\end{array}$ & $\begin{array}{l}15.01 / \\
(1.06)\end{array}$ & Year 2011 & & $\begin{array}{l}9.04 / \\
(0.17)\end{array}$ & $\begin{array}{l}28.60 / \\
(2.24)^{* *}\end{array}$ \\
\hline Year 2012 & & $\begin{array}{l}-10.09 / \\
(-0.19)\end{array}$ & $\begin{array}{l}43.52 / \\
(3.02)^{* * *}\end{array}$ & Year 2012 & & $\begin{array}{l}3.38 / \\
(0.06)\end{array}$ & $\begin{array}{l}51.59 / \\
(3.97)^{* * *}\end{array}$ \\
\hline Year 2013 & & $\begin{array}{l}44.62 / \\
(0.83)\end{array}$ & $\begin{array}{l}86.16 / \\
(6.19)\end{array}$ & Year 2013 & & $\begin{array}{l}72.70 / \\
(1.39)\end{array}$ & $\begin{array}{l}96.12 / \\
(7.51)^{* * *}\end{array}$ \\
\hline Year 2014 & & $\begin{array}{l}77.44 / \\
(1.43)\end{array}$ & $\begin{array}{l}112.15 / \\
(8.07)^{* * *}\end{array}$ & Year 2014 & & $\begin{array}{l}124.15 / \\
(2.36)^{* *}\end{array}$ & $\begin{array}{l}125.79 / \\
(9.84)^{* * *}\end{array}$ \\
\hline Constant & $\begin{array}{l}386.99 / \\
(8.95)^{* * *}\end{array}$ & $\begin{array}{l}371.92 / \\
(7.08)^{* * *}\end{array}$ & $\begin{array}{l}738.11 / \\
(12.48)^{* * *}\end{array}$ & Constant & $\begin{array}{l}-11.38 / \\
(-0.18)\end{array}$ & $\begin{array}{l}-56.15 / \\
(-0.82)\end{array}$ & $\begin{array}{l}685.59 / \\
(12.16)^{* * *}\end{array}$ \\
\hline Adj. $R^{2}$ & 0.16 & 0.16 & & Adj. $R^{2}$ & 0.20 & 0.20 & \\
\hline F-stat & $188.88 * * *$ & $38.97 * * *$ & & F-stat & $251.92 * * *$ & $52.38 * * *$ & \\
\hline $\mathrm{R}^{2}$ overall & & & 0.13 & $\mathrm{R}^{2}$ overall & & & 0.15 \\
\hline Wald $\chi^{2}$ & & & $139.16^{* * *}$ & Wald $\chi^{2}$ & & & $148.37 * * *$ \\
\hline $\mathrm{N}$ & 1002 & 1002 & 1002 & $\mathrm{~N}$ & 1002 & 1002 & 1002 \\
\hline \multirow[t]{2}{*}{$\begin{array}{l}\text { Dependent } \\
\text { Variable }\end{array}$} & \multicolumn{3}{|c|}{ Subsidy Per Undergraduate } & $\begin{array}{l}\text { Dependent } \\
\text { Variable }\end{array}$ & \multicolumn{3}{|c|}{ Subsidy Per Undergraduate } \\
\hline & OLS & OLS & GLS/RE & & OLS & OLS & GLS/RE \\
\hline Variable & \multicolumn{3}{|c|}{ Coefficient/(t- or $Z$-Score) } & Variable & \multicolumn{3}{|c|}{ Coefficient/(t- or $Z$-Score) } \\
\hline Graduation Rate & $\begin{array}{l}-13.59 / \\
(-13.41)^{* * *}\end{array}$ & $\begin{array}{l}-13.80 / \\
(-13.66)^{* * *}\end{array}$ & $\begin{array}{l}-4.69 / \\
(-2.98)^{* * *}\end{array}$ & $\begin{array}{l}\text { ACT } \\
\text { Composite, } \\
25^{\text {th }} \text { Percentile }\end{array}$ & $\begin{array}{l}-95.74 / \\
(-15.93)^{* * *}\end{array}$ & $\begin{array}{l}-97.13 / \\
(-16.25)^{* * *}\end{array}$ & $\begin{array}{l}-20.49 / \\
(-2.73)^{* * *}\end{array}$ \\
\hline Year 2011 & & $\begin{array}{l}41.10 / \\
(0.76)\end{array}$ & $\begin{array}{l}35.80 / \\
(2.82)^{* * *}\end{array}$ & Year 2011 & & $\begin{array}{l}44.82 / \\
(0.81)\end{array}$ & $\begin{array}{l}32.58 / \\
(2.40)^{* *}\end{array}$ \\
\hline Year 2012 & & $\begin{array}{l}79.18 / \\
(1.47)\end{array}$ & $\begin{array}{l}68.63 / \\
(5.38)^{* * * *}\end{array}$ & Year 2012 & & $\begin{array}{l}93.59 / \\
(1.72)^{*}\end{array}$ & $\begin{array}{l}68.46 / \\
(5.04)^{* * *}\end{array}$ \\
\hline Year 2013 & & $\begin{array}{l}130.82 / \\
(2.43)^{* *}\end{array}$ & $\begin{array}{l}111.12 / \\
(8.56)^{* * *}\end{array}$ & Year 2013 & & $\begin{array}{l}151.69 / \\
(2.78)^{* * *}\end{array}$ & $\begin{array}{l}108.94 / \\
(7.87)^{* * *}\end{array}$ \\
\hline Year 2014 & & $\begin{array}{l}174.82 / \\
(3.23)^{* * *}\end{array}$ & $\begin{array}{l}141.05 / \\
(10.49)^{* * *}\end{array}$ & Year 2014 & & $\begin{array}{l}200.64 / \\
(3.66)^{* * *}\end{array}$ & $\begin{array}{l}139.70 / \\
(9.82)^{* * *}\end{array}$ \\
\hline Constant & $\begin{array}{l}1679.16 / \\
(28.86)^{* * *}\end{array}$ & $\begin{array}{l}1605.08 / \\
(24.18)^{* * *}\end{array}$ & $\begin{array}{l}1117.76 / \\
(12.06)^{* * *}\end{array}$ & Constant & $\begin{array}{l}2930.83 / \\
(23.20)^{* * *}\end{array}$ & $\begin{array}{l}2860.96 / \\
(22.12)^{* * *}\end{array}$ & $\begin{array}{l}1294.69 / \\
(8.14)^{* * *}\end{array}$ \\
\hline Adj. $R^{2}$ & 0.15 & 0.16 & & Adj. $R^{2}$ & 0.21 & 0.22 & \\
\hline F-stat & $179.88 * * *$ & $38.97 * * *$ & & F-stat & $253.72 * * *$ & $54.92 * * *$ & \\
\hline $\mathrm{R}^{2}$ overall & & & 0.15 & $\mathrm{R}^{2}$ overall & & & 0.18 \\
\hline Wald $\chi^{2}$ & & & $140.28 * * *$ & Wald $\chi^{2}$ & & & $123.03 * * *$ \\
\hline $\mathrm{N}$ & 1002 & 1002 & 1002 & $\mathrm{~N}$ & 933 & 933 & 933 \\
\hline
\end{tabular}


Our research is consistent with that of Denhart and Vedder (2010) who also examine athletic subsidies on a per-student basis by conference and students' financial and academic capabilities. However, our research has limitations. In particular, the sample is limited to state schools playing at the Division I level. Further research that included private schools and schools playing at the Division II and Division III levels would yield more insight into the size of institutional subsidies going to athletics and to the financial and academic characteristics of the students who pay the bills. Different metrics of students' academic readiness and financial position would also shed additional insight into the questions this study has sought to explore.

In an economic, social, and political climate where the rising cost of higher education, student debt, and student success are of widespread public concern, our findings should be of interest to all who fund higher education, including taxpayers, legislators, students, and their parents.

\section{References}

Alsher, J. (2016). College Sports: 7 Schools That Bring in the Most Money. SportsCheatSheet. December 2. Retrieved from http://www.cheatsheet.com/sports/richest-athletic-departmentscollegesports.html/?a=viewallv

Center for College Affordability and Productivity. (2010). 25 Ways to Reduce the Cost of College, September. Retrieved from http://www.centerforcollegeaffordability.org/uploads/25Ways to Re duce the Cost of College.pdf

Denhart, M., Villwock, R., \& Vedder, R. (2009). The Academics Athletics Trade- off: Universities and Intercollegiate Athletics. Center for College Affordability and Productivity. Retrieved from http://www.centerforcollegeaffordability.org/uploads/athletics.pdf

Denhart, M., Ridpath, D. \& Vedder, R. (2011). Funding the Arms Race: A Case Study of Student Athletic Fees. Center for College Affordability and Productivity. Retrieved from http://www.centerforcollegeaffordability.org/uploads/Funding the

Arms Race.pdf

Denhart, M. \& Vedder, R. (2010). Intercollegiate Athletics Subsidies: A Regressive Tax. Center for College Affordability and Productivity. Retrieved from http://www.centerforcollegeaffordability.org/uploads/ICA Subsidie $\underline{\mathrm{S}}$ RegressiveTax.pdf 
Fort, R. \& Winfree, J. (2013). 15 Sports Myths and Why They're Wrong. Stanford: Stanford University Press.

Frank, R.H. (2004). Challenging the Myth: A Review of the Links among College Athletic Success, Student Quality, and Donations. Report prepared for the Knight Foundation Commission on Intercollegiate Athletics. Retrieved from https://pdfs.semanticscholar.org/68cd/4067f5f9820ee7348a96e29 $\underline{\mathrm{e}}$ 519b5b214238.pdf

Hartsell, J. (2015). Fees fuel smaller colleges' athletics Mid-major schools depend on students. The Post and Courier January 23. Retrieved from http://www.postandcourier.com/sports/fees-fuel-smallercollegesathletics-mid-major-schools-depend-on/article 86d44376c9255f46-8b77-0ba3dca72ed3.html

Kelly, D. \& Dixon, M.A. (2011). Becoming a "Real University:" The Strategic Benefits of Adding Football for NCAA Division I Institutions. Journal of Intercollegiate Sport 4: 283-303.

Lipford, J.W. \& Slice. J.K. (2017). Cost Spreading in College Athletic Spending in the United States: Estimates and Implications. Education Economics 25(4) 379-393.

Litan, R.E., Orszag, J.M. \& Orszag, P.R. (2003). The Empirical Effects of Collegiate Athletics: An Interim Report. Study Commissioned by the National Collegiate Athletic Association. Retrieved from https://www.ncaa.org/sites/default/files/empirical_effects of collegiate at hletics interim report.pdf

McCormick, R.E. \& Tinsley, M. (1987). Athletics versus Academics? Evidence from SAT Scores. Journal of Political Economy 95(5): 11031116.

Mixon, F.G. (1995). Athletics versus Academics? Rejoining the Evidence from SAT Scores. Education Economics 3(3): 277-283.

Mixon, F.G. \& Trevino, L.J. (2005). From Kickoff to Commencement: The Positive Role of Intercollegiate Athletics in Higher Education. Economics of Education Review, 24(1), 97-102.

Mixon, F.G., Trevino, L.J. \& Minto, T.C. (2004). Touchdowns and Test Scores: Exploring the Relationship between Athletics and Academics. Applied Economic Letters 11(7): 421-424.

Orszag, J.M. \& Orszag, P.R. (2005). Empirical Effects of Division II Intercollegiate Athletics. Commissioned by the National Collegiate Athletic 
Who Pays for College Athletic Spending

Association, June. Retrieved from

https://pdfs.semanticscholar.org/d6ae/eb32e37221d62d7acc6ef4429988a6f

$\underline{81 \mathrm{ec} 2 . \mathrm{pdf}}$

Pope, D.G. and Pope, J.C. (2009). The Impact of College Sports Success on the Quantity and Quality of Student Applications. Southern Economic Journal 75(3): 750-780.

Ridpath, D., Fattlar, D. \& Yiamouyiannis, A. (2012). An Examination of NCAA

Division I Football Bowl Championship Subdivision Department Revenues and Expenditures and Their Effect on Athletic Success in a Mid-Major Athletic Conference. The Journal of SPORT 1(1), Article 3. Available at: http://digitalcommons.kent.edu/sport/vol1/iss1/3

Ridpath, D, Smith, J., Garrett, D. \& Robe, J. (2015). Shaping Policy and Practice in Intercollegiate Athletics: A Study of Student Perceptions of Resource Allocation for Athletics and its Effect on Affordability of Higher Education.

The Journal of SPORT 4(1), Article 3. Available at: http://digitalcommons.kent.edu/sport/vol4/iss1/3

Smith, D. R. (2009). College Football and Student Quality: An Advertising Effect or Culture and Tradition. American Journal of Economics and Sociology 68: 553-579.

Stinson, J.L., Marquardt, A. \& Chandley, J. (2012). An Empirical Examination of University Intercollegiate Athletic Expenditures. Sports Marketing Quarterly 21(2):104-114.

Tucker, I. \& Amato, L. (1993). Does big-time success in football or basketball affect SAT scores? Economics of Education Review. 12(2), 177-181.

Toma, J.D. \& Cross, M.E. (1998). Intercollegiate Athletics and Student College Choice: Exploring the Impact of Championship Seasons on Undergraduate

Applications. Research in Higher Education 39(6), 633-661.

Wolverton, B., Hallman, B., Shiflett, S, \& Kambhampati, S. (2015).

The \$10 Billion Sports Tab: How College Students Are Funding the Athletics Arms Race. The Chronicle of Higher Education November 15. Retrieved from http://www.chronicle.com/interactives/ncaasubsidiesmain\#id=table_2014

Zimbalist, A. (2010). Dollar Dilemmas during the Downturn: A Financial Crossroads for College Sports. Journal of Intercollegiate Sport 3: 111124.

Zoda, T. (2012). Can Football Buy Smarter Students? The Effect of Athletic Spending on Football Championship Subdivision Academic Institutions. Issues in Political Economy 21: 82-116. 